\title{
Human Capital Production Function in Strategic Management
}

\author{
Marko Kesti*, Antti Syväjärvi \\ Department of Administrative Sciences, University of Lapland, Rovaniemi, Finland \\ Email: ${ }^{*}$ marko.kesti@ulapland.fi
}

Received 18 December 2014; accepted 2 January 2015; published 13 January 2015

Copyright (C) 2015 by authors and Scientific Research Publishing Inc.

This work is licensed under the Creative Commons Attribution International License (CC BY). http://creativecommons.org/licenses/by/4.0/

c) (i) Open Access

\begin{abstract}
Research-based view studies indicate that companies can distinguish themselves in competition through a profound understanding of their resources and through continuous improvement of their human competencies. It seems that human competencies form an intangible asset, which in turn forms sustainable, unique strengths that are key to firm-specific superior performance. Evidence-based human resource management argues that gaining competitive advantage through human capital development should be verified and estimated scientifically. This article presents the scientifically solid theory of Human Capital Production Function, which explains tangible and intangible human capital's worth to business scorecards in terms of profit and loss account metrics. This article illustrates how Human Capital Production Function explains human resource management's essential role in supporting strategic aims in either achieving cost advantage or differentiation advantage.
\end{abstract}

\section{Keywords}

Human Capital Production Function, Human Resource Management, HRM-Performance, Business Strategy, Productivity

\section{Introduction to Theoretical Background}

Competitive advantage can be defined as achieved specific factor that allows a company to differentiate itself from competitors in its business performance. Business performance can be measured, for example, by market share or profitability. Nowadays many companies' managers believe that their employees' capabilities and motivation represent an indispensable source of competitive advantage [1]. However, managers rightfully want to know how they are doing in relation to competitors and how much they can increase profit by doing something

${ }^{*}$ Corresponding author. 
differently. Performance management's aim is to institute a continuous process of identifying, measuring, and developing organisation performance in all levels and aligning performance with strategic targets [2].

Evidence-based human resource management seeks the best available evidence (data, facts, case studies, research evidence, and theories) to support human resource management decision making. There are multiple management frameworks that aim to gain competitive advantage through human resource management, for example, high-performance work systems, contingency approaches, and the dynamic capabilities view. Fleetwood and Hesketh [3] argue that all these frameworks lack a clear economic explanation for why they should be linked to organisation strategy.

Research reveals that about $95 \%$ of large companies have strategic plans and goals, but only one in eight achieve their strategic goals [4]. The fundamental problem may be that HRM is not properly linked to business strategies. Dessler [1] argues that certain skepticism is needed in linking HRM to business performance because things are not always as they appear and what is intuitively obvious can be misleading. Fleetwood and Hesketh [3] ask for critical realism in exploring the relation between HRM and organisational performance. They argue that explanatory power-not predictive power-is the criteria for evaluating theories that explain HRM's connection to business performance. Scientifically verified HR management practice's correlation to business scorecards is simply not enough; there should also be causal-explanatory methodology that verifies the correlation by quantifying the findings in financial terms [3].

Kesti [5] argues that the traditional production functions do not have the explanatory power to show a company's human capital worth to business performance. Conventional production functions do not show any firmspecific significance of human resources and the worth of human intangible assets development. It seems that strategic learning possibilities that are essential for improving human-related competitive advantages are missing. Kesti has created a new theory of Human Capital Production Function (HCPF) and tested its validity with a longitudinal business case [5]-[7].

The resource-based view takes a strategic approach to achieve a competitive advantage with scarce firm-specific human resources and human competencies [8]-[10]. Competitive advantage is possible when resources are costly to imitate and costly to substitute by competitors [8]. One essential strategic mindset is the flexible use of resources. Sanches [11] states that the resource-based view should offer the ability to respond fast and to be flexible with different demands and challenges in a changing environment. Managing human resource capacity's increases and reductions is one of the most important management issues [12]. Having sustainable competitive advantage requires that scarce human capabilities are not sacrificed in recession and not diluted too much with new personnel at high growth.

Porter [13] identifies three fundamental bases of competitive advantage: cost leadership, differentiation through quality and service, and focus on special market segments. Schuler and Jackson [14] used the Porter model for HR management by recognizing the strategic HRM role in achieving cost reduction, quality enhancement, and innovation. Usually cost reduction focuses on hard HR techniques (staff reduction, cutting training and travelling costs), whereas quality enhancement and innovation focus on soft HR techniques like training, HR development, and staff motivation [15].

\section{A Longitudinal Business Case as a Foundation for Human Capital Production Function}

The phenomenon of Human Capital Production Function was initially found in dissertation research about a longitudinal business case [16]. The case company was a Finnish chain of builders' merchants company named Starkki. The company is part of the Wolseley Corporation, which is one of the world's largest trade distributors of plumbing and heating products and a leading supplier of building materials. Longitudinal research was carried out during 2005 to 2007 in nineteen business units with approximately one thousand employees $(\mathrm{N}=965$, 2005; $N=1065,2006 ; N=1168,2007$ ). The company's business aim is to grow in profitability faster than the competitors. To achieve this goal, each business unit focuses on achieving the best customer service, the best branch staff, and a preferred vendor relationship.

The longitudinal case study was intrinsically interesting from a research point of view: the company consists of nineteen separate yet similar business units, which all perform the same business process with the same staff knowledge resources, with similar HRM practices and customer products. They also all conduct business in a relatively similar market area (Finland). Furthermore, the research was carried out in a steadily growing economic situation in which the Finnish economy's productivity growth was extremely steady during 2005 to 2007, thus involving minimum sources of errors in the economic point of view. Furthermore, during the research 
period, the company concentrated on organic growth with systematic human resource development throughout the organisation. Human resource development (HRD) is the process of facilitating organisational learning, performance, and change through organised interventions, initiatives, and management actions for the purpose of improving organisation performance capacity, capability, competitiveness, and renewal [17].

In the research's longitudinal case study, the fiscal effect of HR development was observed and compared with staff competence surveys from 2005 to 2007. The systematic staff quality of working life (QWL) survey was carried out yearly. The business units can be divided into two sample groups: the units $(\mathrm{N}=10)$ that have increased their QWL and those $(\mathrm{N}=9)$ that have not succeeded in improving their QWL. Figure 1 illustrates that higher QWL increases in the sample group $(\mathrm{N}=10)$ seem to correlate with business improvement. The both sample groups intended to increase revenue capacity by increasing their staff size. The better half $(\mathrm{N}=10)$ increased revenue by $10.9 \%$ (from $22.6 \%$ to $33.5 \%$ ), more than what the staff increase indicates. This means that the revenue increase does not come solely from increased number of staff but presumably from better utilisation of the staff's intangible assets, as the competencies increase was $9.0 \%$. Furthermore, the lower sample group revenue was $4.2 \%$ (from $18.2 \%$ to $22.4 \%$ ) less than the staff increase, and the competence decrease (6.2\%) appears to be in line with this outcome.

In the Figure 1 sample analysis, it appears that the groups that are able to increase their quality of working life can also improve the HCROI (sales margin/staff costs) despite the moderate staff increase. This may be due to the fact that those working societies are able to train new workers more effectively.

\section{Human Capital Production Function}

Human Capital Production Function (HCPF) is applicable to firms where revenue is made through the company's human resources. HCPF has been verified in highly developed business environments where staff costs are high and yearly labor working time is low [5]. In those organisations the labor resources are scarce, creating the foundation for competitive advantage. The organisation development has great impact on staff knowledge utilisation and working time efficiency.

From the strategic management point of view, Human Capital Production Function can be simplified so that it provides illustrative methodology for strategic decision making and analysis. Organisation strategic management includes multiple complex issues that have to be considered together. One single, strategic area optimisation may destroy strategic possibilities in other areas and thus not be optimal for overall strategy. Therefore, I recommend using simplified HCPF in overall strategic decision making. Human Capital Production Function can be simplified with the following Equation (1):

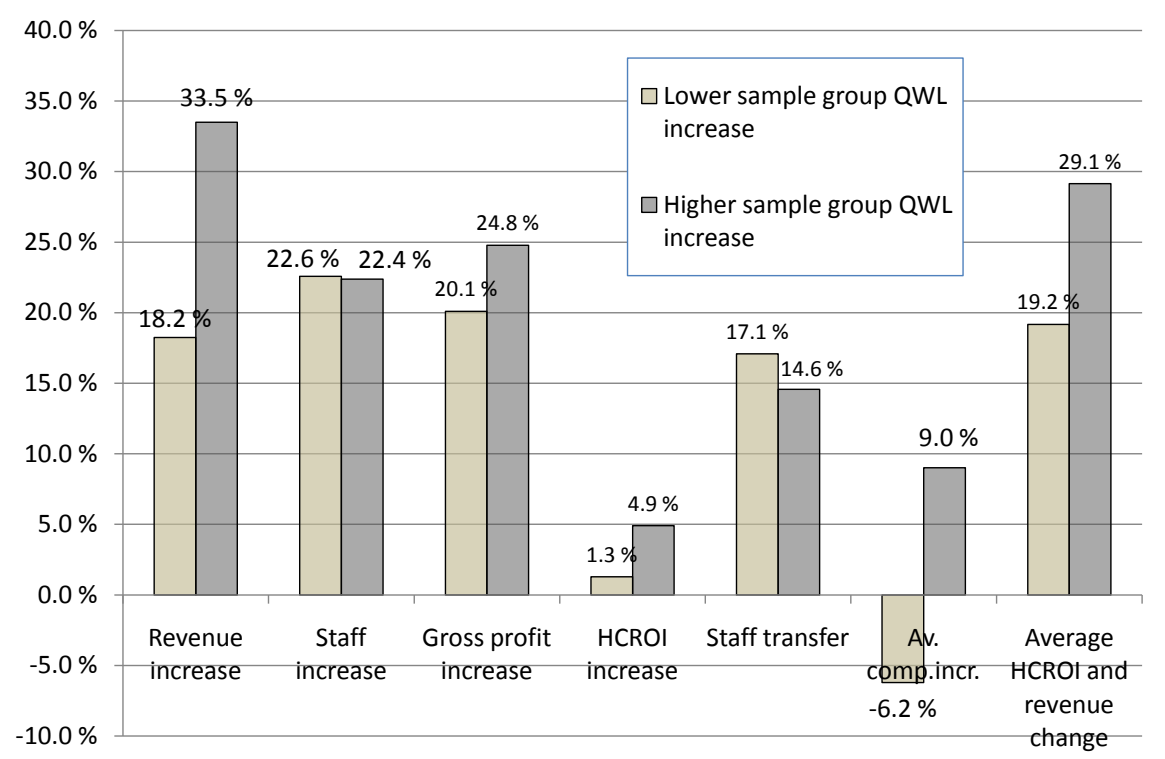

Figure 1. QWL improvement's connection to business improvement in two sample groups. In this figure the HCROI stands for sales margin divided by staff costs. 


$$
R=K * L * T T W *(1-A w) * Q W L
$$

$R=$ Revenue $[\$]$

$K=$ Coefficient for effective working time revenue relation, HR business ratio $[\$ / \mathrm{h}]$

$L=$ Labor capacity of number of employees in full time equivalent [pcs]

$T_{T W}=$ Theoretical yearly working time $[\mathrm{h}]$

$Q W L=$ Labor quality of working life indicating human capital intangible asset utilisation $(0 \%-100 \%)$

$A w=$ Auxiliary working time share of total theoretical working time (e.g. vacation, absences, training, maternity leave, HR practices) [\%]

$(1-\mathrm{Aw})=(100 \%-\mathrm{Aw})=$ Time share available for actual work (time spent at work)

$(1-\mathrm{Aw}) * \mathrm{QWL}=$ Effective working time share from theoretical working time

The profit in EBITDA can be calculated using cost function or profit function according to the following Equation (2):

$$
\text { EBITDA }=\text { Revenue }- \text { Variable Costs }- \text { Staff Costs }- \text { Other Fixed Costs }
$$

The HR Business Ratio (HRBR) determines how much revenue is made in one effective working hour. In the equation it is marked with the letter $K$. This value is calculated from last year's realised data using the following Equation (3):

$$
K=R /(L * T T W *(1-A w) * Q W L)
$$

HRBR $(K)$ is both the business branch ratio and the firm-specific ratio that is dependable on the business logic and the rate of value-added investments in R \& D, processes, IC technology, and production technology. Studying data from the same business branch companies may indicate that the HR Business Ratio could be better. It can be improved by implementing technology and process-quality strategy and by reengineering.

Human Capital Production Function and its connections to strategic perspectives can best be illustrated by Figure 2.

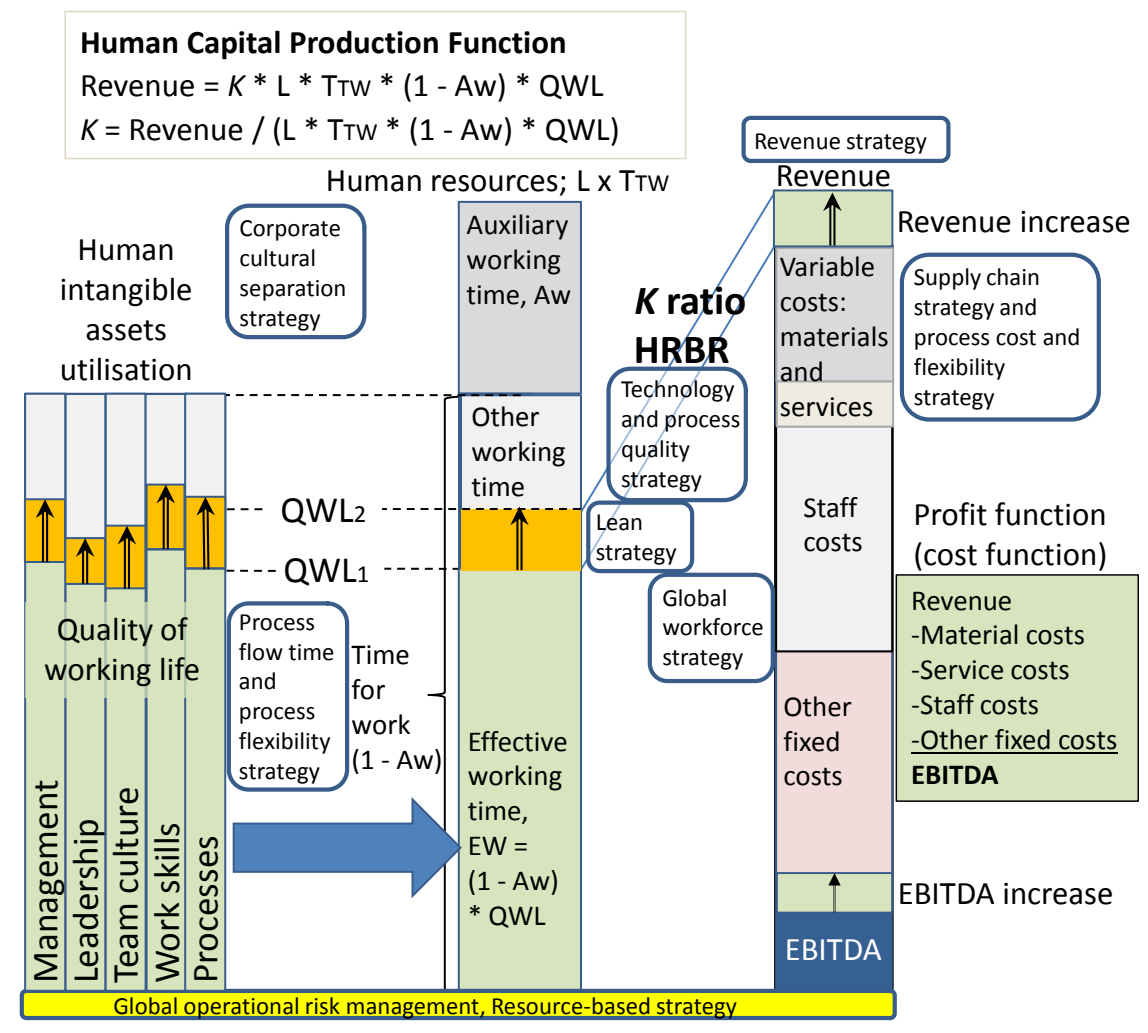

Figure 2. Illustrates the human capital production function principle and its connections to various strategic perspectives. 
Corporate cultural separation and global workforce strategies provide general possibilities to utilise regional knowledge, competencies, and labor cost infrastructure. Revenue strategy focuses on the demand side of the products and services, creating possibilities for optimal growth. Process flow time and process flexibility strategies aim to reduce process lead time and flexible use of process resources. Lean strategy focuses on reducing waste at work processes [18].

Technology and process quality strategies improve firm possibilities to make profitable business, thus trying to increase the HCPF $K$ ratio through R \& D, product quality-prize efficiency, and the use of IC technology. Human Capital Production Function analyses the economic value of human capital and is therefore fundamental part of a firm's global operational risk management.

Naturally, there are several resource-based strategies that can be chosen to meet business goals. In this article I study more closely the so-called HRM-Performance strategy, which is business performance improvement by improving utilisations of human intangible assets, thus improving employee quality of working life. The HRMPerformance (HRM-P) strategy evaluation should include the following studies:

- The HRM-P’s connection with business growth possibilities (revenue and growth management)

o Can the company utilise effective working time increase to make more revenue?

- The HRM-P's connection with human resource cost structure (workforce cost management)

o Can the company make the same revenue with a smaller staff and less overtime work costs?

- The HRM-P's connection with process cost structure (supply chain and process management)

o Can the company make the same revenue with smaller variable service costs?

- The HRM-P's connection with technology strategy (R\&D and business profitability management)

o Can the company make more revenue and profit by technology and product development?

These strategic issues should be considered yearly in management audits, and one or two should be chosen as a strategic focus.

\section{An Example of a Company-Specific, Strategic HCPF Analysis}

The case example study will illustrate the resource-based view HRM-Performance strategy's connection to business performance. Business performance is measured by revenue and operating profit (EBITDA). The case example is a Singaporean business service company of four hundred and forty employees [19]. The case company aims to create competitive advantages through existing or reduced workforce. The initial data is:

$\begin{array}{llll}\text { Yearly working time } & 2288 \mathrm{~h} & \text { Staff size } & 440 \text { employees (FTE) } \\ \text { Vacations } & 6.1 \% & \text { Revenue } & \$ 74,900,760 \\ \text { Absence } & 4.6 \% & \text { Staff costs } & \$ 14,824,920 \\ \text { Maternity leave } & 1.1 \% & \text { Variable costs, materials } & \$ 8,792,080 \\ \text { Training and HR practices } & 1.5 \% & \text { Variable costs, services } & \$ 8,812,320 \\ \text { New workers orientation } & 2.9 \% & \text { Other fixed costs } & \$ 31,528,640 \\ \text { Overtime work } & 2.0 \% & \text { EBITDA } & \$ 10,942,800 \\ \text { Quality of working life } & 75.0 \% \text { (measured by validated employee survey) }\end{array}$

Human intangible assets are identified by an organisation-specific employee survey that measures personnel opinions against essential human competencies. In this article, those human competencies form the quality of working life index. There are several organisation surveys indicating that organisation culture may have a positive correlation with organisation productivity [16] [20]. Syväjärvi and Kesti [21] have introduced an organisation system intelligence model in which the quality of working life index is based on human competencies of management, leadership, subculture, skills, and processes. When HCPF is used in explaining the employee survey results' correlation to business performance, there will be better understanding about the exact causalities as well.

\subsection{HRM-Performance Strategy Connection with Business Growth Possibilities}

When a business is growing it is possible to transform an effective working time increase into revenue growth. Fundamentally, revenue growth requires both market demand and possibilities to increase production capacity. Especially in this case of the business service company, the possibility of making more revenue is good, since service capacity is not so dependable on technological production capacity. The case company invests some staff working time in organisation development, which increases auxiliary working time (Aw), thus decreasing 
time for work $(1-\mathrm{Aw})$. The quality of working life is improved by $5 \%$ units, which eventually lead to $5.8 \%$ increases of effective working time. When the revenue growth strategy can be applied in full efficiency, the revenue increases by $5.8 \%$ (3.9\% units), thus improving revenue by M $\$ 4.3$. Revenue dependable variable costs increase; therefore, when variable costs are subtracted there will remain M\$3.4 more EBITDA (see Figure 3).

\section{Estimating Competitive Advantage}

The company makes $\$ 170,229$ revenue per employee, which is called the Human Capital Revenue Factor (HCRF). M\$4.3 revenue corresponds to twenty-five workers in full time equivalent. The Human Capital Cost Factor (HCCF) is $\$ 33,636$; thus twenty-five persons mean $\$ 840,909$ in staff costs. Let's assume that the average competitor will increase their revenue by increasing their personnel. Because experienced workers are hard to recruit, it is estimated that new workers' contribution to revenue is at half value during an estimated sixth months of orientation time. Thus an M\$4.3 revenue increase requires thirty-three new workers and M\$1.1 in staff costs. Therefore, a competitor revenue growth strategy of increasing staff leads to an EBITDA increase of $\mathrm{M} \$ 2.3(\mathrm{M} \$ 3.4$ - M\$1.1).

It seems that a revenue growth strategy of human capital performance improvement would create a competitive advantage, because the company makes M\$1.1 more EBITDA than its competitor. Furthermore, a competitor's $7.5 \%$ increase in staff size will cause structural organisation challenges because new workers have to be adapted to organisation working groups. Naturally there are several risks in both strategies. Choosing an optimal revenue growth strategy has to be considered carefully, and good HR data is essential in studying the options.

\subsection{The HRM-Performance Strategy's Connection to Cost Leadership Strategy}

When the market declines, the revenue growth strategy is not realistic. The company has to study whether there are possibilities to make the same revenue with lower costs. Cost leadership means better value added; thus cost savings should not compromise the existing revenue. The idea behind HRM-Performance cost leadership is that a staff effective working time increase will substitute possible revenue capacity decline due to cost savings. For example, if overtime work is reduced, there will be cost savings; however, if overtime work is not replaced by more effective work during normal hours, there will be revenue loss, which may cause EBITDA loss that is greater than the cost savings.

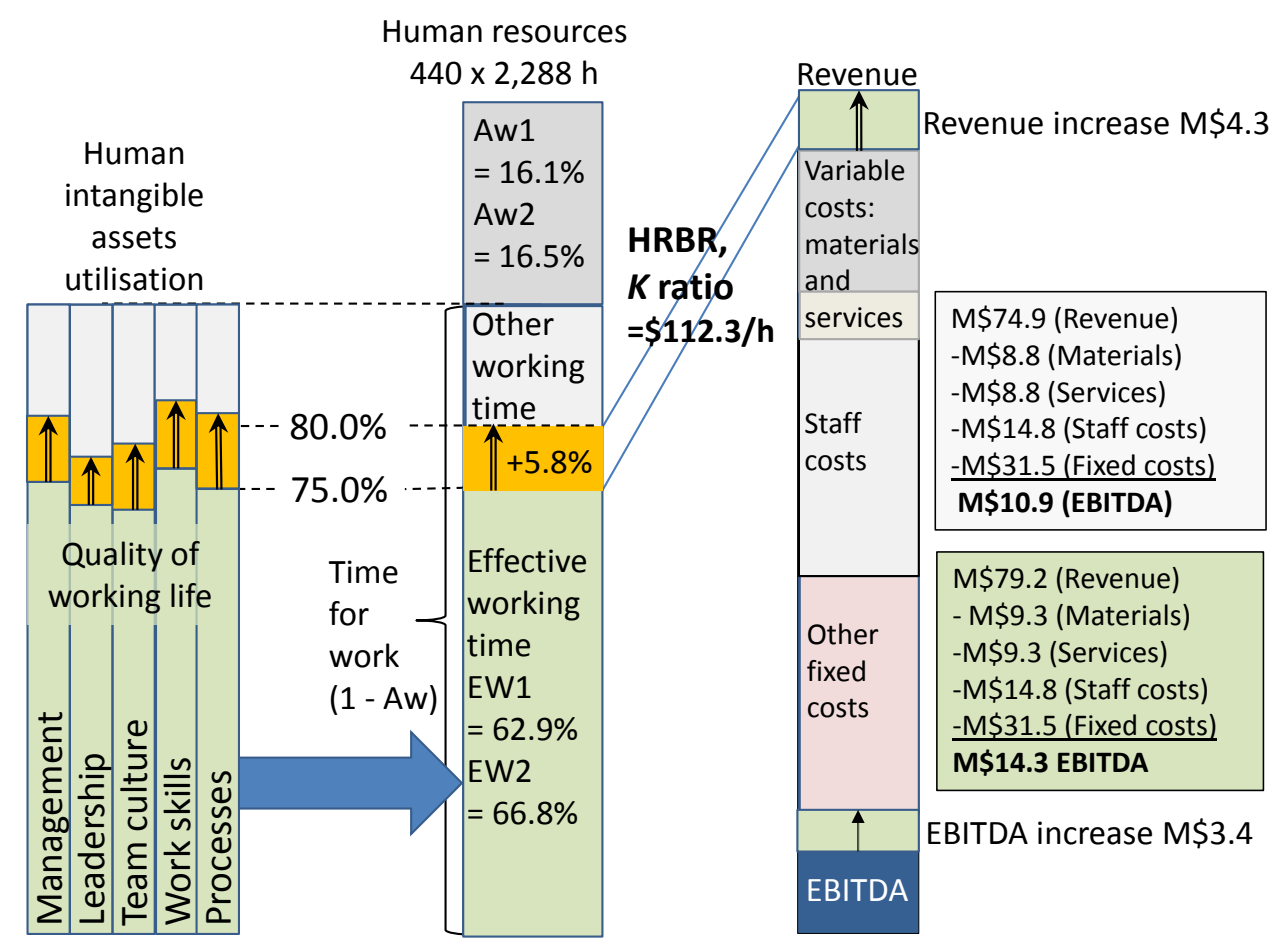

Figure 3. Strategic human resource management's connection to revenue growth strategy. 
The company uses staff working time for effective HR development, which increases auxiliary working time and so decreases time for work. However, effective HR development will improve quality of working life and consequently increase the share of effective working time. Effective HR development means that there will be excess effective working time, which increases labor capacity. In this case it is not possible to increase the revenue; thus the effective working time excess is utilised to achieve cost leadership.

The company purchases some services that they could do themselves if they only had time. A supply strategy cost analysis shows that $5 \%$ of service costs could be replaced by the company's own work. The key question is how much staff working time is needed to substitute service cost savings. This estimation should be on the safe side so as not to sacrifice revenue. The following Equation (4) gives a rough estimation:

$$
\begin{gathered}
\text { FTESC }=S C S *(1-S G M) /(\text { StC } / \text { FTE }) \\
\text { FTESC }=\$ 353,493 *(1-20 \%) /(\$ 14,824,920 / 440)=8.4
\end{gathered}
$$

FTESC = Full time equivalent corresponding, replaceable service costs

SCS = Service Cost Savings potential (in this case \$353,493)

SGM = Service Supplier Gross Margin (in this case 20\%)

$S t C=$ Staff Costs $(\$ 14,824,920)$

$F T E=$ Staff full time equivalent (440)

This equation gives an adequate estimation that the effective working time increase of 8.4 FTE $(1.9 \%$ from total FTE) is needed to substitute the supply service cost savings, which in the HRM-Performance strategy can be achieved through the existing workforce.

The case company HRM-Performance strategy's aim is to maintain revenue and quality with less cost. The company uses contingent labor resources corresponding to $3 \mathrm{FTE}$, and two workers are estimated to retire next year. Furthermore, the company staff does $2 \%$ overtime work, which causes additional staff costs. It is estimated that overtime work could be reduced by half through flexible work organizing and an increase of effective working time. Staff size and overtime work's relation to revenue capacity is relatively easy to calculate. However, qualitative aspects of human resource issues are more difficult to consider, and therefore final decisions must be evaluated thoroughly case by case.

Cost savings are hard decisions, but they are much easier to implement than effective organisation performance development. Cost savings may have negative consequences for revenue and profit, and those destructive cause-effects are extremely difficult to estimate. However, the fact that something is difficult does not make it less important. HRM-Performance may provide a unique competitive advantage in mitigating operative risks of revenue loss. Revenue and profit should not be compromised by shortsighted cost cutting. The HRM-Performance strategy's aim is to plan cost savings so that revenue capacity is not reduced. This analysis can be made using Human Capital Production Function as shown in Table 1.

\section{Estimating Competitive Advantage}

In the case of cost leadership strategy, the company estimates that a realistic goal for organisation development may give approximately $4 \%$ more effective working time. This makes it possible to reduce overtime work, reduce staff numbers (contingent and retirement), and reduce purchased service costs. The total calculated EBITDA improvement is $\$ 733,404$, which in a tough market situation gives the company a competitive advantage. Competitors may focus on reorganizing their workforces with layoffs and other cost reductions, which may jeopardise existing revenue and make things worse. The company's calculated EBITDA improvement is equivalent to 21.8 FTE in staff costs, which with a carefully planned HRM-Performance strategy will make gains without risking existing revenue. Reducing 21.8 employees may save staff costs but at the same time reduce M\$3.7 of revenue capacity and therefore compromise M\$2.1 EBITDA. Reducing workforce is risky, because the wrong amount of layoffs reduces revenue, and furthermore, losing experience is costly in the long term.

\section{Summary and Conclusions}

It is essential to identify effective working time because it determines activity-based costs [22] [23]. Kaplan and Norton [24] address that business scorecards should be balanced so that organisation qualitative human assets are also considered. Effective working time is fundamental, because it determines how much one effective working hour costs and how much revenue it creates. However, it is time consuming to survey employees' 
Table 1. Cost leadership HRM-Performance strategy analysis from human capital productivity analyzing tool.

\begin{tabular}{|c|c|c|c|}
\hline \multicolumn{4}{|c|}{ Productivity analysis initial data } \\
\hline Possibility to utilise & $0 \%$ & for increasing revenue capacity & \\
\hline Possibility to reduce overtime work & $50 \%$ & Overtime work now & $2.0 \%$ \\
\hline & & Possibility to reduce overtime work & $1.0 \%$ \\
\hline Possibility to reduce FTE resources & $1.1 \%$ & FTE decrease in maximum & 5.0 FTE \\
\hline Possibility to reduce service costs & $5.0 \%$ & Cost savings potential & $\$ 352,493$ \\
\hline Service supplier gross margin & $20 \%$ & Corresponding & 8.3 FTE \\
\hline \multicolumn{4}{|c|}{ Productivity improvement substitute analysis } \\
\hline Effective Working Time Increase (EWTI) & $3.97 \%$ & Revenue increase & EBITDA benefit \\
\hline EWTI effect to revenue & $0.00 \%$ & 0 & 0 \\
\hline EWTI effect to service purchase cost savings & $1.90 \%$ & $\$ 2,200,476$ & $\$ 352,493$ \\
\hline & & & $\$ 352,493$ \\
\hline EWTI effect to overtime work decrease & $1.00 \%$ & & $\$ 222,374$ \\
\hline EWTI effect to HR-capacity decrease & $1.07 \%$ & 4.7 FTE & $\$ 158,537$ \\
\hline TOTAL & & & $\$ 733,404$ \\
\hline \multicolumn{4}{|c|}{ Productivity improvement results } \\
\hline Revenue change & & 0 & \\
\hline Staff costs decrease & & $\$ 380,911$ & \\
\hline Staff decrease & & 4.7 FTE & \\
\hline Variable service cost decrease & & $\$ 352,493$ & \\
\hline Operating profit (EBITDA) change & & $\$ 733,404$ & $6.7 \%$ \\
\hline Revenue after change & & $\$ 74,900,760$ & \\
\hline EBITDA after change & & $\$ 11,676,204$ & $15.6 \%$ \\
\hline
\end{tabular}

working time. Kesti [16] has studied how properly validated employee inquiry seems to give an adequate estimation of personnel effective working time when auxiliary working time is known.

Good enterprise resource planning systems should be able to deal with the problem of surveying total time consumed in vacations, absences, maternity leave, training, and other time not actually spent at work. Measuring staff full time equivalent and working time consumption and surveying the quality of working life gives necessary information about total effective working time. Combining effective working time with a firm's business outlook will show the productivity and profitability of an organisation. If an organisation's total effective working time is low compared to its total theoretical yearly working time, there are possibilities to improve labor productivity. If business profits are low even if the organisation works effectively, then it is necessary to improve business profitability. Business profitability can be improved by investments in new products and technology, which improve the HR business ratio (HRBR $=K$ ratio).

This article addresses the problem of human resource performance management's relation to actual business economics and its connections to other strategic evaluations. The research suggests that the examination of tangible and intangible human capital can help management understand how best to utilize the limited human resources to maximize desired outcomes in creating competitive advantage. HR-management is focusing more on strategic business possibilities of human capital management [25] [26]. It seems evident that HR-development provides a foundation on which successful organisation strategy can be built. Although human resources are identified as the most important asset, they are considered so difficult that they are many times almost neglected 
in business strategy considerations. Managers need new tools and methods to be able to prioritise areas that are most important to their firm's business performance.

Measuring quality of working life has to be studied further to identify methods and survey content that correlate with Human Capital Production Function theory (HCPF). Quantifying staff quality of working life is a complex organisation cultural issue and needs more scientifically approved methodologies and case studies. Furthermore, the organisation's efficiency development is essential to study because that is the key to achieving HRM-Performance results. This article indicates that besides helping to achieve the strategic aim, HRM could participate in strategic planning so that an organisation can gain even more economic value or mitigate potential risks in advance, and in this way create excellent human resources organisation.

\section{References}

[1] Dessler, G. (2011) Human Resource Management. Pearson Education Limited, Upper Saddle River.

[2] Aguinis, H. (2007) Performance Management. Prentice Hall, Upper Saddle River.

[3] Fleetwood, S. and Hesketh, A. (2010) Explaining the Performance of Human Resource Management. Cambridge University Press, Cambridge. http://dx.doi.org/10.1017/CBO9780511781100

[4] Kaplan, R. and Norton, D. (2005) The Office If Strategy Management. Harward Business Review, October 2005, 72-80.

[5] Kesti, M. (2013) Human Capital Production Function. GSTF Journal on Business Review, 3, 22-32. http://dx.doi.org/10.7603/s40706-013-0001-7

[6] Kesti, M. and Syväjärvi, A. (2012) Human Resource Development Function to Both Organizational Performance and Quality of Working Life. Journal of Global Business Review GBR, 2, 135-141.

[7] Kesti, M. and Syväjärvi, A. (2013) Human Resource Intangible Assets Connected to the Organizational Performance and Productivity. In: Ravindran, A. and Shirazi, F., Eds., Business Review: Advanced Applications, Cambridge Scholars Publishing, Cambridge, 136-173.

[8] Barney, J.B. (1991) Firm Resources and Sustainable Competitive Advantage. Journal of Management, 17, 99-120. http://dx.doi.org/10.1177/014920639101700108

[9] Mahoney, J. and Pandian, J.R. (1992) The Resource-Based View within the Conversation of Strategic Management. Strategic Management Journal, 13, 363-380. http://dx.doi.org/10.1002/smj.4250130505

[10] Grant, R.M. (1991) The Resource-Based Theory of Competitive Advantage. California Management Review, 33, 114135. http://dx.doi.org/10.2307/41166664

[11] Sanches, R. (1995) Strategic Flexibility in Product Competition. Strategic Management Journal, 16, 135-159. http://dx.doi.org/10.1002/smj.4250160921

[12] Ambrosini, V. and Bowma, C. (2009) What Are Dynamic Capabilities and Are They a Useful Construct in Strategic Management? International Journal of Management Reviews, 11, 29-49.

[13] Porter, M. (1985) Competitive Advantage: Creating and Sustaining Superior Performance. Free Press, New York.

[14] Schuler, R. and Jackson, S. (1997) Linking Competitive Strategies with Human Resource Management. Academy of Management Executive, 1, 207-219. http://dx.doi.org/10.5465/AME.1987.4275740

[15] Beardwell, J. and Claydon, T. (2010) Human Resource Management: A Contemporary Approach. 6th Edition, Prentice Hall, Englewood Cliff.

[16] Kesti, M. (2012) The Tacit Signal Method at Human Competence Based Organization Performance Development. University of Lapland, Rovaniemi.

[17] Gilley, J. and Maycunich, A. (1998) Strategically Integrated HRD: Partnering to Maximize Organizational Performance. Perseus Publishing, Cambridge.

[18] Yeming, G. (2013) Global Operations Strategy. Springer, Berlin.

[19] Kesti, M. (2014) Human Capital Production Function at Analyzing Company Specific Competitive Advantage Strategies. The International Conference on Business Strategy and Social Sciences, Kuala Lumbur, 16-17 August 2014.

[20] Ehrhart, M.G., Schneider, B. and Macey, W.H. (2014) Organizational Climate and Culture. Routledge, New York.

[21] Syväjärvi, A. and Kesti, M. (2012) Positive Human Tacit Signal Approach and Competence System Intelligence in Organization. In: Di Fabio, A., Ed., Emotional Intelligence-New Perspectives and Applications, InTech Publications, Rijeka, European Union, 139-166. http://dx.doi.org/10.5772/31044

[22] Kaplan, R.S. (2006) Time-Driven Activity-Based Costing. Harvard Business School Case N9-106-068, Harvard Business School, Boston. 
[23] Kaplan, R.S. and Anderson, S.R. (2006) Time-Drive-Activity-Based Costing. Harvard Business School Press, Boston.

[24] Kaplan, R. and Norton, D. (2012) The Strategy-Focused Organization: How Balanced Scorecard Companies Thrive in the New Business Environment. Harvard Business School Press, Boston.

[25] Van Buren III, H., Greenwood, M. and Sheehan, C. (2011) Strategic Human Resource Management and the Decline of Employee Focus. Human Resource Management Review, 21, 209-219. http://dx.doi.org/10.1016/j.hrmr.2011.02.004

[26] Jackson, S., Schuler, R. and Jiang, K. (2014) An Aspirational Framework for Strategic Human Resource Management. The Academy of Management Annals, 8, 1-56. http://dx.doi.org/10.1080/19416520.2014.872335 
Scientific Research Publishing (SCIRP) is one of the largest Open Access journal publishers. It is currently publishing more than 200 open access, online, peer-reviewed journals covering a wide range of academic disciplines. SCIRP serves the worldwide academic communities and contributes to the progress and application of science with its publication.

Other selected journals from SCIRP are listed as below. Submit your manuscript to us via either submit@scirp.org or Online Submission Portal.
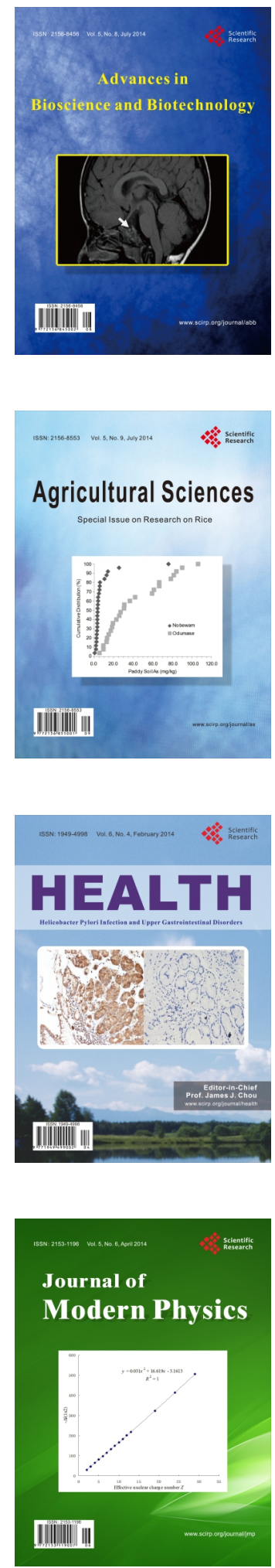
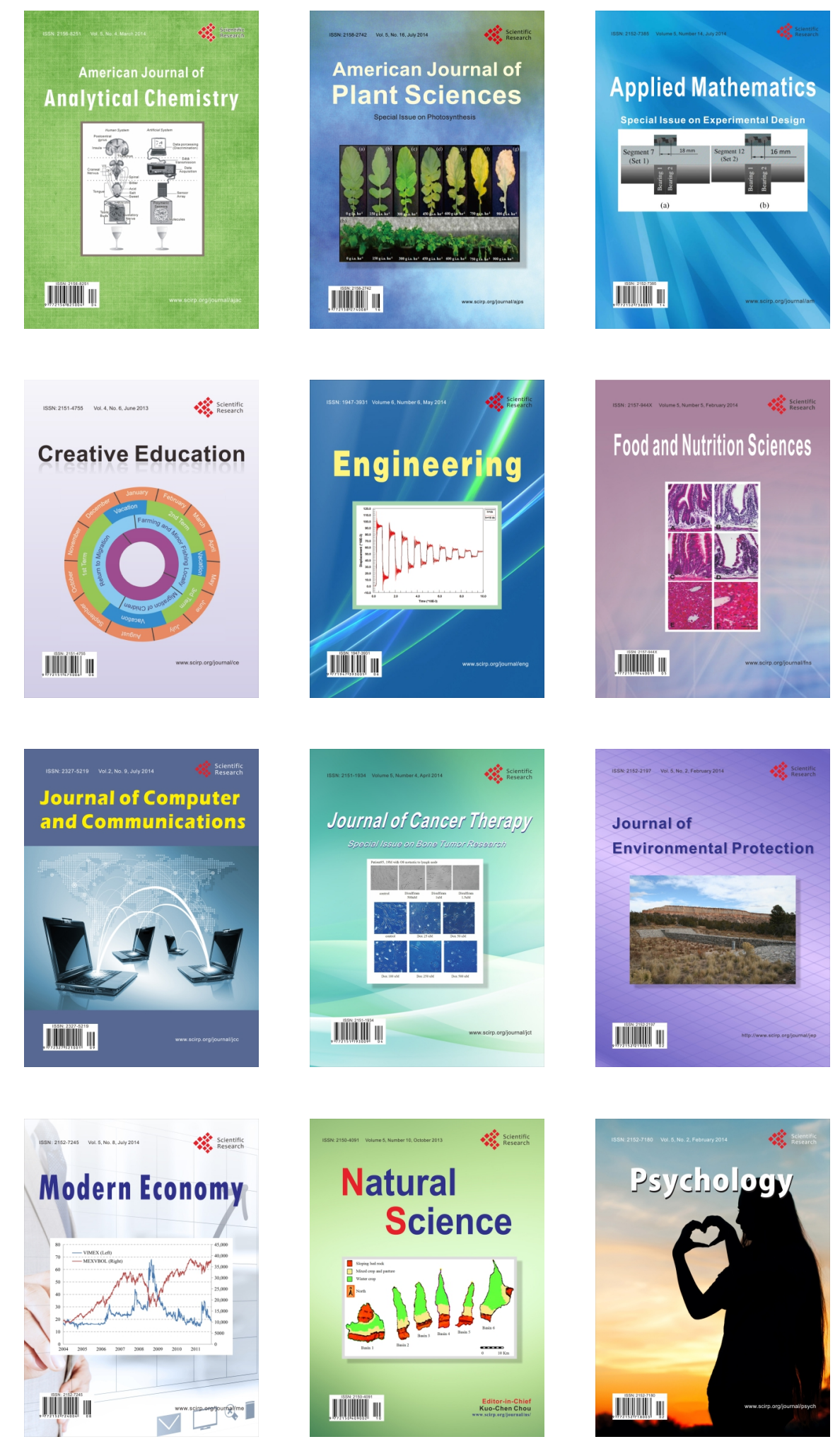